\title{
1994/95 AMS/Industry Undergraduate Scholarships
}

In the fall of 1994, the American Meteorological Society joined with 11 leading environmental science and service corporations to offer undergraduate scholarships in the atmospheric and related oceanic and hydrologic sciences. We would like to take this opportunity to once again thank the sponsoring corporations for their continued support of the AMS/Industry Undergraduate Scholarship Program. The corporations that joined with the Society in this program and the recipients of these scholarships are listed below. The recipients of the $\$ 4000$ scholarships received $\$ 2000$ in the fall of 1994 , and will receive a subsequent $\$ 2000$ this fall as they enter their senior year.*

\section{UPDATE}

\section{HUGHES STX CORPORATION}

Hughes STX Corporation provides multidisciplinary scientific and engineering services in space, earth, and environmental systems. Hughes STX is a wholly owned subsidiary of Hughes Aircraft Company. Ryan J. Zerr is a student at the University of North Dakota and will receive a degree in meteorology.

\section{SCIENCE AND TECHNOLOGY CORPORATION}

Science and Technology Corporation is a leader in atmospheric sciences and related remote sensing research, development, and engineering activities. Sonya C. Kulkarni is a student at The Pennsylvania State University and will graduate with a degree in meteorology.

\section{THE MITRE CORPORATION}

The MITRE Corporation is an independent, not-forprofit system engineering firm engaged in scientific and technical activities for the public benefit. MITRE assists government agencies in both the defense and civilian sectors. Greg C. Liknes is a student at the University of North Dakota and will graduate with a degree in meteorology.

\footnotetext{
*See the July 1994 issue of theBulletin of the American Meteorological
} Society for a complete write-up.

\section{CONCURRENT COMPUTER} CORPORATION

Concurrent Computer Corporation is the industry's leading specialist in real-time, high performance, opensystems-based solutions for specific markets. Concurrent has over 25 years of information systems experience. Mark J. Gibbas is a student at Plymouth State College and will graduate with a degree in meteorology.

ATMOSPHERIC AND ENVIRONMENTAL RESEARCH, INC.

Atmospheric and Environmental Research, Inc. (AER) provides government and industry with research and consulting services in the global environmental sciences. It is a key contributor to major national meteorological programs such as the next generation of the Defense Meteorological Satellite Program and the Automated Weather Information Processing System. David A. Ahijevych is a student at Valparaiso University and will graduate with a degree in meteorology and mathematics.

CAMPBELL SCIENTIFIC, INC.

Campbell Scientific, Inc. has become a leading designer and manufacturer of environmental data acquisition instrumentation. The company maintains an expertise in sensor theory and field measurement practices. Daniel P. Lara is a student at the College of Santa Fe and will graduate with a degree in chemistry and environmental science. 


\section{AAI SYSTEMS MANAGEMENT INCORPORATED}

AAI Systems Management Incorporated is the prime contractor of the federal government's Automated Surface Observing Systems (ASOS). ASOS, an integral part of the NWS modernization program, provides an automated observing capability with the most modern complement of weather sensors on the market today. Ryan J. Sharp is a student at The Florida State University and will graduate with a degree in meteorology and physics.

\section{R.M. YOUNG COMPANY}

R.M. Young Company specializes in the development and manufacture of instruments for surface meteorological measurements. The company has earned a reputation for producing cost-effective, quality instrumentation. Noah $\mathbf{M}$. Nigg is a student at Purdue University and will graduate with a degree in atmospheric sciences.

\section{SURFACE SYSTEMS, INC.}

Surface Systems, Inc. is a successful, high-technology company that manufactures and markets ad- vanced weather sensing systems and weather forecasting services to the transportation industry. Douglas E. Murphy is a student at Purdue University and will graduate with a degree in atmospheric science.

\section{ENTERPRISE ELECTRONICS CORPORATION}

Enterprise Electronics Corporation (EEC) has been the worldwide leader of advanced weather radar systems since its inception in 1971. EEC developed the first commercial Doppler weather radar for meteorological use in 1980. EEC has more than 600 weather radar installations worldwide. Julie R. Givan is a student at The Florida State University and will graduate with a degree in meteorology and mathematics.

\section{WSI CORPORATION}

WSI Corporation is a leader in serving customers whose operations depend on the highest quality weather information services. WSI provides customers with real-time, value-added weather data and imagery, as well as powerful software packages and sophisticated workstations. Brian P. Mackey is a student at The Florida State University and will graduate with a degree in meteorology.

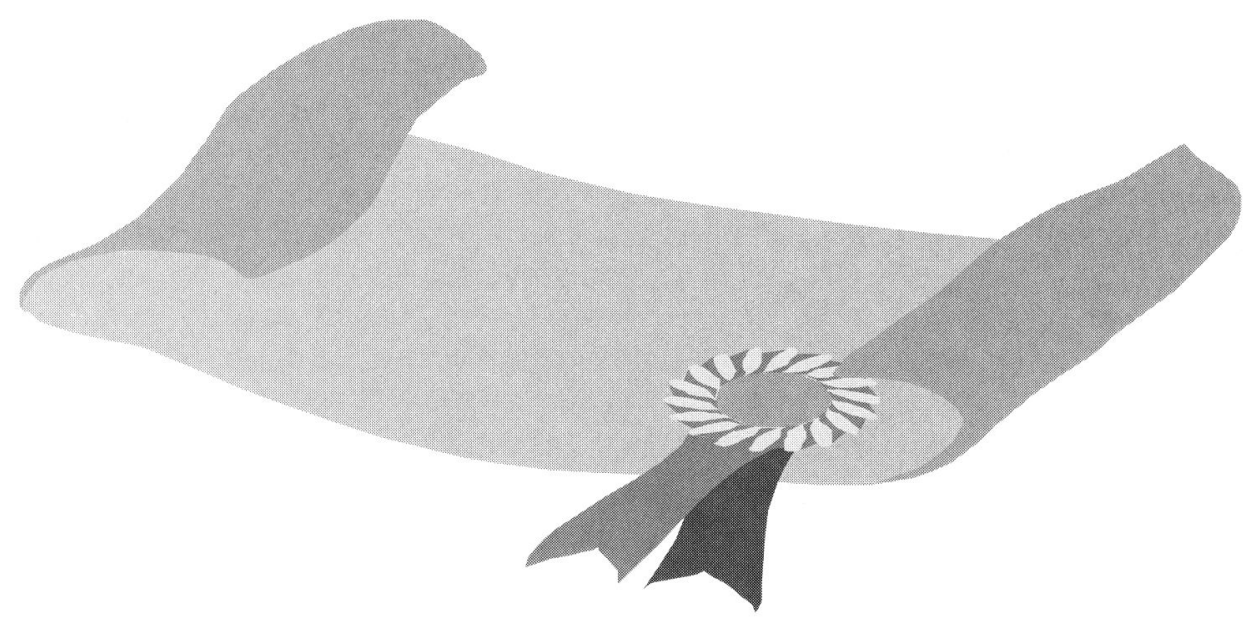

